\title{
Impact of Organomineral Fertilization Systems on the Yield of Field Crops and Changes in the Productivity of Crop Rotation on Irrigated Ordinary Carbonate Chernozems of the Central Ciscaucasia
}

\author{
Ruslan Bizhoev, Sarina Konova, Asiyat Sarbasheva, Olga Batyrova, and Rada Gazheva \\ Institute of Agriculture - Branch of the Kabardino-Balkarian Scientific Center of the Russian \\ Academy of Sciences, Kirova Street, 224, 360004 Nalchik, Kabardino-Balkarian Republic
}

\begin{abstract}
The paper presents the research results of the impact of different fertilization systems - mineral and organic, using intercropping of green manure crops, biological resources (straw of grain crops, foliar of maize) on crop yields of grain rotating crops - winter wheat, maize, peas and the productivity of hectare of arable black land of ordinary carbonate chernozem in dryland conditions of the Central Caucasus region with different indicators of growing seasons. The scientific novelty of the paper is the identification of optimum-rational fertilization systems and the justification of the influence of the studied fertilization systems and the use of byproducts of the crop rotation, which make it possible to obtain stable crop yields and maintain the humus content in the soil. The work defines the efficiency of the use of different mineral fertilizer doses in combination with organic fertilizers, which form the highest crop yield and crop rotation productivity.
\end{abstract}

\section{Introduction}

The use of organic and mineral fertilizers is the most important tool in the system of agronomic measures to ensure stable crop yields. It is most effective in a certain system with existing crop rotation (agrocenosis), since only such application takes into account, as much as possible, not only the action but also the consequence of both organic and mineral forms. Only a science-based fertilization system in each crop rotation can provide planned crop yields while maintaining soil fertility $[1,2,3]$.

The combined impact of these agricultural inputs on crop productivity and soil fertility can only be assessed through long-term stationary field studies.

It is known that, in the current economic climate, agricultural producers are forced to use fewer mineral fertilizers than the recommended norms for their specific farming conditions. This is primarily due to the cost and expenses of application, as well as the incomplete assembly of the market with the necessary fertilizers [4]. In this regard, research has studied the impact of different mineral fertilizer norms (full norm, half and one third of the recommended norm) when combined with organic fertilizers such as manure, green manure 
or straw, as well as their integrated application to winter wheat, maize, peas and crop rotation productivity.

\section{Materials and Methods}

The work was performed in a long-term stationary field experiment territorially located in Krasnoarmeysk village, Tersky district, Kabardino-Balkarian Republic on the experimental field of the Institute of Agriculture of the Kabardino-Balkarian Scientific Center of the Russian Academy of Sciences [5,6]. The experiment founded in 1979 and included in the Register of Long-term Experiments, registration No. 082, under the name "To develop technology of biological reproduction of the fertility of irrigated soil on the basis of the use of different types of organic fertilizers and rational use of mineral fertilizers in the agricultural landscape system of Kabardino-Balkarian Republic" [7,8]. Research is conducted according to classical methods. Annual reports on R\&D are submitted to the Geographic Network, where the federal database is updated [9].

The experiments are based on a 9-grain field rotation with the following crop rotation: 1 - peas, 2 - winter wheat, 3-4 - dried maize, 5 - winter wheat, 6 - sunflower, 7 - winter wheat, 8 - dried maize, 9 - winter wheat. The experiment is based in the space of three fields, the alternation of crops in the fields of crop rotation occurs in time with the successive entry of fields into the crop rotation. Agricultural techniques for crop cultivation followed zonal guidelines. There are 60 options in the experiment, 240 plots, the plot area is $189 \mathrm{~m}^{2}$ with a plot width of $6.3 \mathrm{~m}$ and a length of $30.0 \mathrm{~m}$. Fertilizers were applied according to a scheme of experiment.

Ammonium nitrate, simple and double superphosphate, potassium salt, semi-rotted manure were used as fertilizers. Variants and norms for different types of organic fertilizers are presented in Table 1. NPK norms are established on the basis of actual experimental material and are recommended as optimal in the area of cultivation.

In recent years, ammonium nitrate, ammophos and nitroammophos have been used due to the lack and cost of the required fertilizers, in particular superphosphate and potassium fertilizer.

\section{Results and discussion}

In 2018, in grain-and-grass crop rotations, according to the rotation Camilla maize was cultivated in 1 field, Cheget winter wheat in field 2, and Rassvet peas in field 3.

In this experiment, peas had an undoubted advantage as a predecessor (Table 1). The yield of Cheget winter wheat in control option 1 without fertilizers for peas in 2018 was $46.2 \mathrm{dt} / \mathrm{ha}$. The formation of such a yield was facilitated not only by weather conditions, but also by better timely soil preparation, planting crops at optimal times, the advantage of a good predecessor, and adherence to other agricultural practices.

In field 2 of the crop rotation according to the predecessor peas in option 2 with the use of the recommended mineral fertilization system - $\mathrm{N}_{90} \mathrm{P}_{120} \mathrm{~K}_{60}$ - the grain yield of Cheget winter wheat of $65.8 \mathrm{dt} / \mathrm{ha}$ was achieved. The effectiveness of the recommended mineral fertilizer system in options $6,10,14,18$ when combined with organic resources (aftereffect of manure, green manure, grain straw, their complex application) by $11.5,12.3,13.2,18,8 \mathrm{~kg} / \mathrm{ha}$ more than in variant 2, without organic fertilizers, which contributed to the grain yield of Cheget winter wheat after peas in 2018 , respectively: 77.3; 78.1; 79.0; $84.6 \mathrm{dt} / \mathrm{ha}$. 
Table 1. Impact of organo-mineral fertilization systems on yields of maize, winter wheat and peas in the variants of field experience of 1979, dt/ha, 2018.

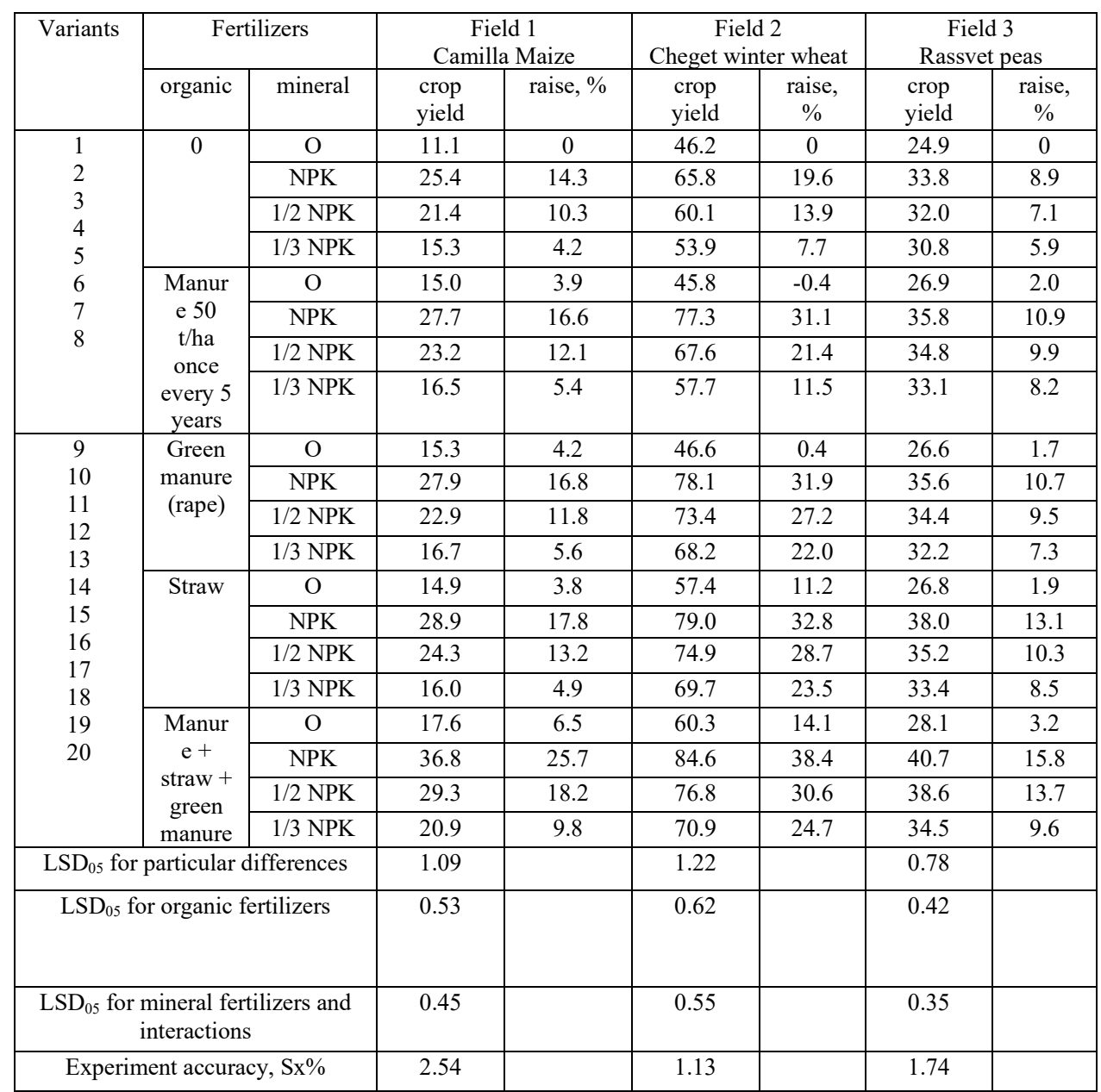

The reduction of recommended mineral fertilizer doses by half $(1 / 2 \mathrm{RD}$ - options 7.11.15.19) reduced the yield of irrigated crop rotation by $9-10 \%$ compared to the yield at the full dose of fertilizers. The decrease in winter wheat and other crops yields at $1 / 3$ of the recommended dose was $17-18 \%$.

The productivity of 1 ha of grain-and-grass crop rotation without fertilizer under irrigation (option 1) of the experiment in 2018 was $30.0 \mathrm{dt} /$ ha (Table 2).

Analyzing the productivity of 1 crop rotation hectare with long-term use of different organic fertilization systems, we can conclude that it increases in the experimental options compared to control. 
Table 2. Change in the productivity of crop rotation fields by crops and fertilization systems in the variants of the 1979 field experiment in 2018, dt.g.u./ha.

\begin{tabular}{|c|c|c|c|c|c|c|}
\hline \multirow{2}{*}{$\begin{array}{l}\text { Vari } \\
\text { ants }\end{array}$} & \multicolumn{2}{|c|}{ Fertilizers } & \multirow{2}{*}{$\begin{array}{c}\text { Field } 1 \text { - } \\
\text { maize } \\
\text { Camilla SV }\end{array}$} & \multirow{2}{*}{$\begin{array}{l}\text { Field } 2 \text { - } \\
\text { winter } \\
\text { wheat } \\
\text { Cheget }\end{array}$} & \multirow{2}{*}{$\begin{array}{l}\text { Field 3- } \\
\text { peas } \\
\text { Rassvet }\end{array}$} & \multirow[t]{2}{*}{ Average } \\
\hline & $\begin{array}{l}\text { organi } \\
\text { c }\end{array}$ & mineral & & & & \\
\hline \multirow{8}{*}{$\begin{array}{l}1 \\
2 \\
3 \\
4 \\
5 \\
6 \\
7 \\
8\end{array}$} & \multirow[t]{4}{*}{0} & 0 & 8.9 & 46.2 & 34.9 & 30.0 \\
\hline & & NPK & 20.3 & 65.8 & 47.3 & 44.5 \\
\hline & & $1 / 2 \mathrm{NPK}$ & 17.1 & 60.1 & 44.8 & 40.7 \\
\hline & & 1/3 NPK & 12.2 & 53.9 & 43.1 & 36.4 \\
\hline & \multirow{4}{*}{$\begin{array}{c}\text { Manur } \\
\text { e, } \\
50 \mathrm{t} / \mathrm{ha} \\
\text { (once } \\
\text { every } \\
5 \\
\text { years) } \\
\text { afteref } \\
\text { fect }\end{array}$} & 0 & 12.0 & 45.8 & 37.7 & 31.8 \\
\hline & & NPK & 22.2 & 77.3 & 50.1 & 49.9 \\
\hline & & $1 / 2 \mathrm{NPK}$ & 18.6 & 67.6 & 48.7 & 45.0 \\
\hline & & $1 / 3 \mathrm{NPK}$ & 13.2 & 57.7 & 46.3 & 39.1 \\
\hline \multirow{12}{*}{$\begin{array}{c}9 \\
10 \\
11 \\
12 \\
13 \\
14 \\
15 \\
16 \\
17 \\
18 \\
19\end{array}$} & \multirow{4}{*}{$\begin{array}{l}\text { Green } \\
\text { manur } \\
\mathrm{e}\end{array}$} & 0 & 12.2 & 46.6 & 37.2 & 32.0 \\
\hline & & NPK & 22.3 & 78.1 & 49.8 & 50.1 \\
\hline & & $1 / 2 \mathrm{NPK}$ & 18.3 & 73.4 & 48.2 & 46.6 \\
\hline & & 1/3 NPK & 13.4 & 68.2 & 45.1 & 42.2 \\
\hline & \multirow[t]{4}{*}{ Straw } & 0 & 11.9 & 57.4 & 37.5 & 35.6 \\
\hline & & NPK & 23.1 & 79.0 & 53.2 & 51.8 \\
\hline & & $1 / 2 \mathrm{NPK}$ & 19.4 & 74.9 & 49.3 & 47.9 \\
\hline & & $1 / 3 \mathrm{NPK}$ & 12.8 & 69.7 & 46.8 & 43.1 \\
\hline & \multirow{4}{*}{$\begin{array}{c}\text { Manur } \\
\mathrm{e}+ \\
\text { straw } \\
+ \\
\text { green } \\
\text { manur } \\
\text { e }\end{array}$} & 0 & 14.0 & 60.3 & 39.3 & 37.9 \\
\hline & & NPK & 29.4 & 84.6 & 57.0 & 57.0 \\
\hline & & $1 / 2 \mathrm{NPK}$ & 23.4 & 76.8 & 54.0 & 51.4 \\
\hline & & $1 / 3 \mathrm{NPK}$ & 16.7 & 70.9 & 48.3 & 45.3 \\
\hline
\end{tabular}

The climatic conditions of the 2019 growing season were very unfavourable for the growth, development and production of all field crops. During the autumn period of 2018 from September to December inclusive - $51.2 \mathrm{~mm}$ of precipitation fell at a rate of $110.7 \mathrm{~mm}$, which did not even allow winter wheat to grow in the autumn, despite the optimal planting time.

The relative air humidity in all months of growing season was less than the annual average by $2-14 \%$. The climatic indicators were particularly unfavourable in June 2019.

In the first field of the experiment, after maize, Camilla SV maize was cultivated, the hybridization plot, in the second field after winter wheat, also Camilla SV maize, in the third field after peas - Cheget winter wheat.

Research has shown that the yield of Cheget winter wheat in field 3 under the predecessor of peas in 2019 was 2.0-2.4 times lower than that of wheat in previous years of research. In variant 2, the recommended mineral fertilization system achieved a grain yield of Cheget winter wheat of only $27.7 \mathrm{dt} / \mathrm{ha}$ (Table 3 ).

The efficiency of the recommended mineral fertilization system, when combined with organic resources, in options 6,10,14,18 (after manure, green manure, straw, integrated application) is $2.3,1.5,2.0,5.3 \mathrm{dt} /$ ha higher, than in variant 2 , without organic fertilizers, which contributed to Cheget winter wheat grain yields under peas in 2019, respectively: 30.0; $29.2 ; 29.7 ; 33.0 \mathrm{dt} / \mathrm{ha}$. 
The reduction of the recommended mineral fertilizer rate by half $(1 / 2 \mathrm{RD}$ - options $7,11,15,19)$ reduced crop yields with irrigation in 2019 by $16-19 \%$ compared to total fertilizer yield. The crop yield decrease at $1 / 3$ of the recommended dose was $30-39 \%$.

The highest yields in Cheget winter wheat of $33.0 \mathrm{dt} / \mathrm{ha}$ and Camille maize of $70.7 \mathrm{dt} / \mathrm{ha}$ were achieved in 2019 in option 18 with the recommended mineral fertilizer rate combined with the integrated application of all studied bioresources.

Table 3. Impact of organo-mineral fertilization systems on the yield of corn and winter wheat in the variants of the 1979 field experiment, $\mathrm{kg} / \mathrm{ha}, 2019$.

\begin{tabular}{|c|c|c|c|c|c|c|c|c|}
\hline \multirow[t]{2}{*}{ Variants } & \multicolumn{2}{|c|}{ Fertilizers } & \multicolumn{2}{|c|}{$\begin{array}{c}\text { Field } 1 \\
\text { Camilla SV maize, } \\
\text { 1st generation }\end{array}$} & \multicolumn{2}{|c|}{$\begin{array}{c}\text { Field } 2 \\
\text { Camilla SV } \\
\text { maize, } 1 \mathrm{st} \\
\text { generation }\end{array}$} & \multicolumn{2}{|c|}{$\begin{array}{c}\text { Field } 3 \\
\text { Cheget winter } \\
\text { wheat }\end{array}$} \\
\hline & organic & mineral & $\begin{array}{l}\text { crop } \\
\text { yield }\end{array}$ & $\begin{array}{c}\text { raise, } \\
\%\end{array}$ & $\begin{array}{l}\text { crop } \\
\text { yield }\end{array}$ & $\begin{array}{c}\text { rais } \\
\mathrm{e}, \\
\%\end{array}$ & $\begin{array}{c}\text { crop } \\
\text { yiel } \\
\text { d } \\
\end{array}$ & $\begin{array}{c}\text { raise, } \\
\%\end{array}$ \\
\hline \multirow{8}{*}{$\begin{array}{l}1 \\
2 \\
3 \\
4 \\
5 \\
6 \\
7 \\
8\end{array}$} & \multirow[t]{4}{*}{0} & $\mathrm{O}$ & 24.9 & 0 & 21.6 & 0 & 17.6 & 0 \\
\hline & & NPK & 53.4 & 28.5 & 36.0 & $\begin{array}{c}14 . \\
4\end{array}$ & 27.7 & 10.1 \\
\hline & & $1 / 2 \mathrm{NPK}$ & 43.3 & 18.4 & 31.9 & $\begin{array}{c}10 . \\
3\end{array}$ & 23.0 & 5.4 \\
\hline & & $1 / 3 \mathrm{NPK}$ & 32.1 & 7.2 & 27.4 & 5.8 & 19.9 & 2.3 \\
\hline & \multirow{4}{*}{$\begin{array}{l}\text { Manure } 50 \\
\text { t/ha } \\
\text { once every } \\
5 \text { years }\end{array}$} & $\mathrm{O}$ & 32.8 & 7.9 & 23.9 & 2.3 & 17.9 & 0.3 \\
\hline & & NPK & 55.8 & 30.9 & 37.9 & $\begin{array}{c}16 . \\
3\end{array}$ & 30.0 & 12.4 \\
\hline & & $1 / 2 \mathrm{NPK}$ & 47.7 & 22.8 & 33.8 & $\begin{array}{c}12 . \\
2\end{array}$ & 24.1 & 6.5 \\
\hline & & $1 / 3 \mathrm{NPK}$ & 38.4 & 13.5 & 28.0 & 6.4 & 20.6 & 3.0 \\
\hline \multirow{12}{*}{$\begin{array}{c}9 \\
10 \\
11 \\
12 \\
13 \\
14 \\
15 \\
16 \\
17 \\
18 \\
19 \\
20\end{array}$} & \multirow{4}{*}{$\begin{array}{l}\text { Green } \\
\text { manure } \\
\text { (rape) }\end{array}$} & $\mathrm{O}$ & 27.1 & 2.2 & 26.1 & 4.5 & 18.2 & 0.6 \\
\hline & & NPK & 52.7 & 27.8 & 41.2 & $\begin{array}{c}19 . \\
6\end{array}$ & 29.2 & 11.6 \\
\hline & & $1 / 2 \mathrm{NPK}$ & 43.8 & 18.9 & 35.7 & $\begin{array}{c}14 . \\
1\end{array}$ & 25.1 & 7.5 \\
\hline & & $1 / 3 \mathrm{NPK}$ & 36.1 & 11.2 & 32.8 & $\begin{array}{c}11 . \\
2\end{array}$ & 20.1 & 2.5 \\
\hline & \multirow[t]{4}{*}{ Straw } & $\mathrm{O}$ & 30.6 & 5.7 & 23.8 & 2.2 & 18.7 & 1.1 \\
\hline & & NPK & 56.3 & 31.4 & 41.0 & $\begin{array}{c}19 . \\
4\end{array}$ & 29.7 & 12.1 \\
\hline & & $1 / 2 \mathrm{NPK}$ & 48.2 & 23.3 & 33.4 & $\begin{array}{c}11 . \\
8\end{array}$ & 26.3 & 8.7 \\
\hline & & $1 / 3 \mathrm{NPK}$ & 36.6 & 11.7 & 27.8 & 6.2 & 19.7 & 2.1 \\
\hline & \multirow{4}{*}{$\begin{array}{l}\text { Manure + } \\
\text { straw }+ \\
\text { green } \\
\text { manure }\end{array}$} & $\mathrm{O}$ & 35.7 & 10.8 & 28.7 & 7.1 & 20.6 & 3.0 \\
\hline & & NPK & 70.7 & 45.8 & 43.4 & $\begin{array}{c}21 . \\
8\end{array}$ & 33.0 & 15.4 \\
\hline & & $1 / 2 \mathrm{NPK}$ & 60.7 & 35.8 & 37.0 & $\begin{array}{c}15 . \\
4\end{array}$ & 29.9 & 12.3 \\
\hline & & 1/3 NPK & 40.1 & 15.2 & 35.0 & $\begin{array}{c}13 . \\
4 \\
\end{array}$ & 22.8 & 5.2 \\
\hline \multicolumn{3}{|c|}{$\mathrm{LSD}_{05}$ for particular differences } & 1.93 & & 0.82 & & 0.67 & \\
\hline \multicolumn{3}{|c|}{$\mathrm{LSD}_{05}$ for organic fertilizers } & 0.96 & & 0.41 & & 0.15 & \\
\hline \multicolumn{3}{|c|}{$\begin{array}{l}\mathrm{LSD}_{05} \text { for mineral fertilizers and } \\
\text { interactions }\end{array}$} & 0.84 & & 0.37 & & 0.22 & \\
\hline \multicolumn{3}{|c|}{ Experiment accuracy, $\mathrm{Sx} \%$} & 4.23 & & 1.02 & & 1.00 & \\
\hline
\end{tabular}

Low crop yields (Table 4) compared to previous research years have affected the productivity of 1 ha of crop rotation. Analyzing the productivity of 1 crop rotation hectare, 
we can conclude that it differs in different options of experiments in comparison with the control - the cultivation of crops without fertilizers. In 2019, the production of 1 hectare of crop area without fertilizer in control was at the same level of 17.3-19.9 dt.g.u. for both winter wheat and maize.

Table 4. Change in the productivity of crop rotation fields by crops and fertilization systems in the options of the 1979 field experience in 2018 and 2019, dt.g.u/ha.

\begin{tabular}{|c|c|c|c|c|c|c|c|}
\hline \multirow[t]{2}{*}{ Variants } & \multicolumn{2}{|c|}{ Fertilizers } & \multirow{2}{*}{$\begin{array}{c}\text { Field } 1 \\
\text { - maize } \\
\text { Camilla } \\
\text { SV }\end{array}$} & \multirow{2}{*}{$\begin{array}{c}\text { Field } 2 \\
\text { maize } \\
\text { Camilla } \\
\text { SV }\end{array}$} & \multirow{2}{*}{$\begin{array}{c}\text { Field } 3 \text { - } \\
\text { Cheret } \\
\text { winter } \\
\text { wheat } \\
\end{array}$} & \multicolumn{2}{|c|}{$\begin{array}{c}\text { Medium } \\
\text { productivity }\end{array}$} \\
\hline & organic & mineral & & & & 2018 & 2019 \\
\hline \multirow{8}{*}{$\begin{array}{l}1 \\
2 \\
3 \\
4 \\
5 \\
6 \\
7 \\
8\end{array}$} & \multirow[t]{4}{*}{0} & 0 & 19.9 & 17.3 & 17.6 & 30.0 & 18.3 \\
\hline & & NPK & 42.7 & 28.8 & 27.7 & 44.5 & 33.1 \\
\hline & & $1 / 2 \mathrm{NPK}$ & 34.6 & 25.5 & 23.0 & 40.7 & 27.7 \\
\hline & & $1 / 3 \mathrm{NPK}$ & 25.7 & 21.9 & 19.9 & 36.4 & 22.5 \\
\hline & \multirow{4}{*}{$\begin{array}{c}\text { Manure, } \\
50 \mathrm{t} / \mathrm{ha} \\
\text { (once } \\
\text { every } 5 \\
\text { years) } \\
\text { aftereffect }\end{array}$} & 0 & 26.2 & 19.1 & 17.9 & 31.8 & 21.1 \\
\hline & & NPK & 44.6 & 30.3 & 30.0 & 49.9 & 35.0 \\
\hline & & $1 / 2 \mathrm{NPK}$ & 38.2 & 27.0 & 24.1 & 45.0 & 29.8 \\
\hline & & $1 / 3 \mathrm{NPK}$ & 30.7 & 22.4 & 20.6 & 39.1 & 24.6 \\
\hline \multirow{12}{*}{$\begin{array}{c}9 \\
10 \\
11\end{array}$} & \multirow{4}{*}{$\begin{array}{l}\text { Green } \\
\text { manure }\end{array}$} & 0 & 21.7 & 20.9 & 18.2 & 32.0 & 20.3 \\
\hline & & NPK & 42.2 & 33.0 & 29.2 & 50.1 & 34.8 \\
\hline & & $1 / 2 \mathrm{NPK}$ & 35.0 & 28.6 & 25.1 & 46.6 & 29.6 \\
\hline & & $1 / 3 \mathrm{NPK}$ & 28.9 & 26.2 & 20.1 & 42.2 & 25.1 \\
\hline & \multirow[t]{4}{*}{ Straw } & 0 & 24.5 & 19.0 & 18.7 & 35.6 & 20.7 \\
\hline & & NPK & 45.0 & 32.8 & 29.7 & 51.8 & 35.8 \\
\hline & & $1 / 2 \mathrm{NPK}$ & 38.6 & 26.7 & 26.3 & 47.9 & 30.5 \\
\hline & & $1 / 3 \mathrm{NPK}$ & 29.3 & 22.2 & 19.7 & 43.1 & 23.7 \\
\hline & \multirow{4}{*}{$\begin{array}{c}\text { Manure + } \\
\text { straw }+ \\
\text { green } \\
\text { manure }\end{array}$} & 0 & 28.6 & 23.0 & 20.6 & 37.9 & 24.1 \\
\hline & & NPK & 56.6 & 34.7 & 33.0 & 57.0 & 41.4 \\
\hline & & $1 / 2 \mathrm{NPK}$ & 48.6 & 29.6 & 29.9 & 51.4 & 36.0 \\
\hline & & $1 / 3 \mathrm{NPK}$ & 32.1 & 28.0 & 22.8 & 45.3 & 27.6 \\
\hline
\end{tabular}

In 2020, in the experiment, Yuzhanka winter wheat was cultivated in field 1, after the Camilla SV maize, in field 2, after the Cheget winter wheat, Karat maize, in field 3, after the Cheget winter wheat, Karat maize.

In 2020, peas also showed an advantage as a predecessor in the experiment. The yield of Yuzhanka winter wheat in control variant 1, without fertilizers, according to the predecessor corn was $17.3 \mathrm{dt} / \mathrm{ha}$, which is almost the same as the yield of winter wheat in 2019 , the difference in yield did not exceed the smallest significant difference for this factor (Table 5). 
Table 5. Impact of organo-mineral fertilization systems on the yield of corn and winter wheat in the variants of the 1979 field experiment, $\mathrm{kg} / \mathrm{ha}, 2020$.

\begin{tabular}{|c|c|c|c|c|c|c|c|c|}
\hline \multirow[t]{2}{*}{ Variants } & \multicolumn{2}{|c|}{ Fertilizers } & \multicolumn{2}{|c|}{$\begin{array}{c}\text { Field } 1 \\
\text { Yuzhanka winter } \\
\text { wheat }\end{array}$} & \multicolumn{2}{|c|}{$\begin{array}{c}\text { Field } 2 \\
\text { Karat maize }\end{array}$} & \multicolumn{2}{|c|}{$\begin{array}{c}\text { Field } 3 \\
\text { Karat maize }\end{array}$} \\
\hline & $\begin{array}{c}\text { organi } \\
\mathrm{c}^{2}\end{array}$ & mineral & $\begin{array}{l}\text { crop } \\
\text { yield }\end{array}$ & $\begin{array}{c}\text { raise, } \\
\%\end{array}$ & $\begin{array}{l}\text { crop } \\
\text { yield }\end{array}$ & raise, $\%$ & $\begin{array}{l}\text { crop } \\
\text { yield }\end{array}$ & raise, $\%$ \\
\hline \multirow{9}{*}{$\begin{array}{l}1 \\
2 \\
3 \\
4 \\
5 \\
6 \\
7 \\
8\end{array}$} & \multirow[t]{5}{*}{0} & $\mathrm{O}$ & 17.3 & 0 & 30.7 & 0 & 28.5 & 0 \\
\hline & & NPK & 29.0 & 11.7 & 51.6 & 20.9 & 53.7 & 25.2 \\
\hline & & $1 / 2 \mathrm{NPK}$ & 23.6 & 6.3 & 46.7 & 16.0 & 44.7 & 16.2 \\
\hline & & 1/3 NPK & \multirow{2}{*}{\multicolumn{2}{|c|}{20.0}} & \multirow[t]{2}{*}{45.2} & \multirow[t]{2}{*}{14.5} & \multirow[t]{2}{*}{32.6} & \multirow[t]{2}{*}{4.1} \\
\hline & & & & & & & & \\
\hline & \multirow{4}{*}{$\begin{array}{l}\text { Manur } \\
\text { e } 50 \\
\text { t/ha } \\
\text { once } \\
\text { every } \\
5 \\
\text { years }\end{array}$} & $\mathrm{O}$ & 18.7 & 1.4 & 30.9 & 0.2 & 35.3 & 6.8 \\
\hline & & NPK & 29.8 & 12.5 & 55.1 & 24.4 & 57.0 & 28.5 \\
\hline & & $1 / 2 \mathrm{NPK}$ & 23.4 & 6.1 & 50.1 & 19.4 & 48.8 & 20.3 \\
\hline & & $1 / 3 \mathrm{NPK}$ & 20.5 & 3.5 & 47.2 & 16.5 & 38.6 & 8.2 \\
\hline \multirow{12}{*}{$\begin{array}{c}9 \\
10 \\
11 \\
12 \\
13 \\
14 \\
15 \\
16 \\
17 \\
18 \\
19 \\
20\end{array}$} & \multirow{4}{*}{$\begin{array}{c}\text { Green } \\
\text { manur } \\
\text { e } \\
\text { (rape) }\end{array}$} & $\mathrm{O}$ & 18.4 & 1.1 & 31.0 & 0.3 & 28.5 & 0 \\
\hline & & NPK & 29.0 & 11.7 & 52.1 & 21.4 & 54.0 & 25.5 \\
\hline & & $1 / 2 \mathrm{NPK}$ & 24.8 & 7.5 & 49.2 & 18.5 & 44.3 & 15.8 \\
\hline & & $1 / 3 \mathrm{NPK}$ & 20.2 & 2.9 & 48.2 & 16.5 & 36.3 & 7.8 \\
\hline & \multirow[t]{4}{*}{ Straw } & $\mathrm{O}$ & $\begin{array}{ll}18.2 \\
18.8\end{array}$ & 1.5 & 31.3 & 0.6 & 30.7 & 2.0 \\
\hline & & NPK & 29.7 & 12.4 & 54.4 & 23.7 & 58.3 & 29.8 \\
\hline & & $1 / 2$ NPK & 26.0 & 8.7 & 51.3 & 20.6 & 49.1 & 20.6 \\
\hline & & $1 / 3 \mathrm{NPK}$ & 19.7 & 2.4 & 48.1 & 17.4 & 38.3 & 9.8 \\
\hline & \multirow{4}{*}{$\begin{array}{c}\text { Manur } \\
\mathrm{e}+ \\
\text { straw } \\
+ \\
\text { green } \\
\text { manur } \\
\mathrm{e}\end{array}$} & $\mathrm{O}$ & 20.7 & 3.4 & 34.5 & 3.8 & 37.3 & 8.8 \\
\hline & & NPK & 33.0 & 15.7 & 61.9 & 31.2 & 71.4 & 42.9 \\
\hline & & $1 / 2 \mathrm{NPK}$ & 30.8 & 13.5 & 57.7 & 27.0 & 60.8 & 32.3 \\
\hline & & $1 / 3$ NPK & 22.8 & 5.5 & 53.1 & 22.4 & 41.4 & 12.9 \\
\hline \multicolumn{3}{|c|}{$\mathrm{LSD}_{05}$ for particular differences } & 0.23 & & 1.22 & & 1.46 & \\
\hline \multirow{2}{*}{\multicolumn{3}{|c|}{$\begin{array}{l}\mathrm{LSD}_{05} \text { for organic fertilizers } \\
\mathrm{LSD}_{05} \text { for mineral fertilizers and } \\
\text { interactions }\end{array}$}} & 0.34 & & 0.62 & & 0.74 & \\
\hline & & & 0.30 & & 0.55 & & 0.66 & \\
\hline \multicolumn{3}{|c|}{ Experiment accuracy, Sx\% } & 1.03 & & 1.13 & & 2.84 & \\
\hline
\end{tabular}

The effectiveness of the recommended mineral fertilization system when combined with organic resources in options $6,10,14,18$ (manure aftereffect, green manure, straw, their complex application) by $0.8 ; 0.0 ; 0.7 ; 4.3 \mathrm{dt} /$ ha more than in variant 2 , without organic fertilizers and amounted to: $29.8 ; 29.0 ; 29.7 ; 33.0 \mathrm{dt} / \mathrm{ha}$.

The application of the recommended mineral fertilization systems, combined with the aftereffect and action of organic fertilizers (option 6,10,14,18), increased crop yields. Reducing the recommended mineral fertilizer doses by half $(1 / 2 \mathrm{RD}$ - options $7,11,15,19)$ reduced the yield of irrigated crop rotation by $13-15 \%$ compared to the yield at the full dose of fertilizers. The crop yield decrease at $1 / 3$ of the recommended dose was $27-30 \%$. The obtained yield indicators are processed mathematically, they are reliable.

The productivity of 1 crop rotation hectare also differs significantly in the direction of increase in the options of experiments in comparison with the control. 
Studies have shown that it is recommended to use all possible techniques to replenish organic matter in the soil, especially in irrigation: manure application, straw dressing, maize foliar and other plant residues, as well as the cultivation of green manure crops.

\section{Conclusion}

Based on the research results conducted in 2018-2020, the following conclusions can be drawn:

1. The use of the recommended mineral fertilization system $\left(\mathrm{N}_{90} \mathrm{P}_{120} \mathrm{~K}_{60}\right)$ in irrigation resulted in an increase in winter wheat yield of 10.0-19.6 dt/ha and in maize of 14.3-28.5 $\mathrm{dt} / \mathrm{ha}$ compared to unprofitable cultivation.

2. The reduction of recommended mineral fertilizer doses by half ( $1 / 2 \mathrm{RD})$, reduced crop yields from 9 to $19 \%$ per year in crop rotation compared to crop yields with a full dose of fertilizers. With the use of $1 / 3$ of the recommended dose of mineral fertilizers, the decrease in the yield of winter wheat and other crops of crop rotation was $17-39 \%$.

3. The highest crop yield was produced in variants with the application of the fully recommended mineral fertilization system.

4. The highest crop yield for the period of research was formed in the 18 variant of the experiment, where the recommended full rate was applied and in different years according to the prevailing climatic conditions it was $83-88$ for winter wheat and $101-232 \%$ higher for maize than without the use of fertilizers.

5. The productivity of 1 crop rotation hectare in different variants of experiments was 1.1-2.3 times, or 0.5-29.9 dt/ha higher than that of controlled crops without fertilizer.

\section{References}

1. A. S. Shpakov, Adaptive Feed Production: Problems and Solutions (2002)

2. E. D. Adinyaev Cultivation of corn under irrigation (1988)

3. V.I. Kiryushin, Agriculture, 5 (2) (1987)

4. T. P. Lifanenkova, R.V. Bizhoev, Alternative methods of reproduction of fertility of irrigated chernozem of ordinary steppe zone of the Central Ciscaucasia (2011)

5. B. A. Armor, Field experiment technique (1985)

6. F. A. Yudin, Methods of Agrochemical Research, 11, 16, 100 (1971)

7. Guidelines for conducting research in long-term experiments with fertilizers, 1 (1975)

8. Guidelines for research in long-term experiments with fertilizers, 2 (1983)

9. Register of long-term experiments with fertilizers and other agrochemicals of the Russian Federation (2005) 